\title{
Archaeology of the Slavic Migrations
}

Michel Kazanski

Most archaeologists associate the Roman-period Proto-Slavs with the Kiev culture in the middle and upper Dnieper basin, kindred to it sites of the type Zaozer'e in the upper Dnieper and the upper Dvina basins, and finally the groups of sites of the type

Cherepyn-Teremtsy in the upper Dniester basin and of the type Ostrov in the Pripyat basin. The fate of the early Slavs was much influenced by the events on the early stage of the Great Migration, when the Huns attacked the Goths in 375 CE. In the Dnieper area, from the mid-5th century CE on, the lands of the Goths were gradually taken by the populations of early Slavic cultures, who moved there from the upper Dnieper region. For the age of Slavic migrations from the $5^{\text {th }}$ to the 7 th centuries CE, most archaeologists have identified the Slavs with the Prague culture, some of the sites of the Ipoteşti-Cîndeşti, the Penkovka culture, the Kolochin culture, and far to the north the Long Barrows culture, at least partially relatable to some Slavic or Balto-Slavic population. There are two specific aspects of the archaeology of Slavic migrations: the movement of the populations of the Slavic cultural model and the diffusion of this model amid non-Slavic population. Several stages and directions are associated with the Slavic migrations of the $5^{\text {th }}-8$ th centuries CE:

- migration into the forest-steppe zone of Eastern Europe (5th c. CE);

- migrations in the lower Danube area (late $5^{\text {th }}$ - early 6 th cc. CE);

- migration south of the Danube and into the Balkans (6th-7th cc. CE);

- migration in the middle and upper Danube areas (mid-6th-7th cc. CE);

- migration into the Vistula, Oder, and Elbe basins (6th-7th cc. CE); and

- migration in the forest area of Eastern Europe ( 7 th-9th cc. CE).

From an archaeological point of view, these migrations are manifested in the spread of Slavic cultural traits (related to handcrafted ceramics, types of buildings, cremation tombs, and female costume), and, for the southern part of the area, they are confirmed by the testimony of written sources.

In archaeological research on Slavic antiquities, the following schema comprising three chronological stages has been increasingly accepted (see e.g., Stanciu 2015: 165):

- Proto-Slavs, corresponding to the Wends (Venedi, Venethi, Veneti, Ouenedai) of ancient sources (Roman period, 1st-4th cc. CE);

- Early Slavs, i.e., the Antes (Antae, Antai, Anti) and the Sclaveni (Sklavenoi, Sklavinoi) of the writers from the Late Antiquity and Early Middle Ages (mid-5th to the middle or the second half of the 7 th c. CE); 
- Medieval Slavs, from the second half or the late 7 th century CE on.

Most archaeologists relate the Roman-period Proto-Slavs with the Kiev (Kyiv) culture in the middle and upper Dnieper basin, akin to it sites of the type Zaozer'e in the upper Dnieper and the upper Dvina basins, and finally the groups of sites of the type Cherepyn-Teremtsy in the upper Dniester basin and of the type Ostrov in the Pripyat basin (Ščukin et al. 2006: 57-59; Kazanski 1999: 21-37; map 1). This identification corresponds to Tret'jakov's hypothesis that the Slavs formed a specific ethnic group in the Roman period in the southern area of the forest zone of Eastern Europe mostly in the upper Dnieper basin (Tret'jakov 1966; 1970; 1982). To judge by hydronyms, this part of the Dnieper basin located to the north of present-day Kyiv once was a part of the Balto-Slavic linguistic unity. Moreover, it was located rather far away of the Roman imperial borders, which possibly explains why Roman and Greek writers' accounts of the Wends were so laconic.

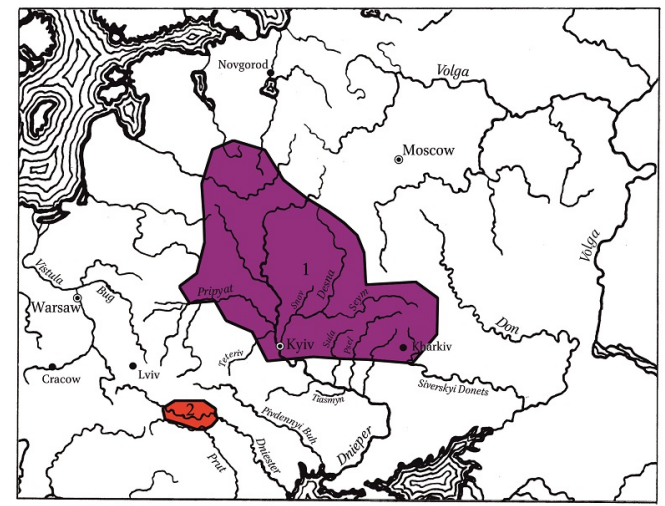

Map 1: Archaeological civilizations of the 3 rd-4th centuries CE attributable to the Proto-Slavic population. 1 - Kiev (Kyiv) civilization and its northern variants; 2 - sites of the Dniester and Pripyat basins with ceramics related to the Prague civilization. Due to the scale of the map, the zones of archaeological civilizations are shown approximately.

The fate of the early Slavs was much influenced by the events of the early stage of the Great Migration, when the Huns attacked the Goths, who from the $3^{\text {rd }}$ to the first half of the $5^{\text {th }}$ century CE had resided in the lands to the south of the area populated by the Slavs and caused them to leave Eastern Europe in $375^{-455}$ CE. In the Dnieper area, from the mid-5th century CE on, the territory of the Goths was gradually taken by the populations of early Slavic cultures, who moved there from the upper Dnieper region (Tret'jakov 1966: 271; 1970: 92-99; 1982: 92-114; Ščukin et al. 2006: 153, 154). To the west of it, in the territory between the Dniester and the Pripyat, in this period the leading role passed to the population who lived there since the Roman period and possessed some traits typical of the Slavic Prague culture in the later period (Ščukin et al. 2006: 155, 156).

For the period of Slavic migrations from the $5^{\text {th }}$ to the 7 th century CE (map 2), most Slavic archaeologists have identified the Slavs proper, or the "Sclaveni" of written sources, with the Prague culture, which occupied the area between the Dnieper and the Elbe (Rusanova 1976; Sedov 1995: 7-39; Kazanski 1999: 83-96), and some of the sites of the Ipoteşti-Cîndeşti culture located in the lands to the north of the lower Danube, which possessed some Slavic cultural component (Teodor 1978; 1994; Sedov 1995: 95-108). According to its geographical location, the Penkovka (Pen'kivka) culture in the forest-steppe zone from the Donets to the 
Prut corresponds to the "Antes" of ancient writers (Sedov 1995: 68-94; Prixodnjuk 1998; Kazanski 1999: 96-120). To the north of the Penkovka culture, mostly in the upper Dnieper basin, there is the area of the Kolochin (Koločin) culture (Kazanski 1999: 120-125; Oblomskij 2016), whose origin was the same with the Penkovka culture, and therefore it has been interpreted as Slavic. To the northwest of it, in the upper Dvina basin, is the territory of the Bancerovščyna culture, usually related to the Balts (Mitrofanov 1978: 84-150; Šadyra 2006: 45-106), and far to the north is the Long Barrows culture, at least partially relatable to some Slavic or Balto-Slavic population (Sedov 1995: 211-217; Mixajlova 2014; Islanova 2016: 136-150; map 2). All the listed groups of archaeological sites have many common features and are notable for extreme archaism.

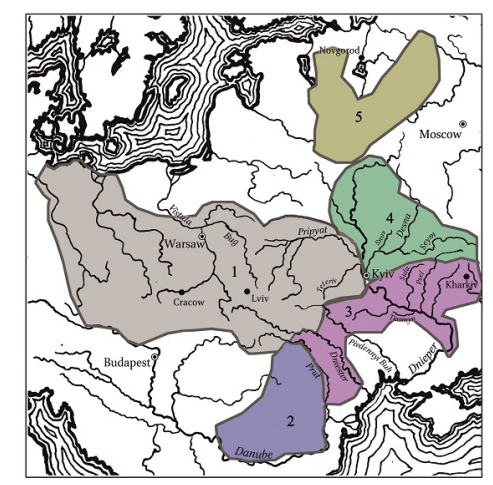

Map 2: Archaeological civilizations of the $5^{\text {th }}-7_{\text {th }}$ centuries CE attributable to Slavs. 1 - Prague and Sukow-Dziedzice; 2 Ipoteşti-Cîndeşti; 3 - Penkovka (Pen'kivka); 4 - Kolochin (Koločin); 5 - civilization of the Pskov long barrows. Due to the scale of the map, the distribution zones of archaeological civilizations are shown approximately.

Archaeologists have interpreted the Prague culture as predominantly Slavic, mostly due to genetic continuity of the 5 th-to-7th-century CE antiquities and undoubtedly Slavic cultures in Central and Eastern Europe dating from the 8th and gth centuries CE. The Prague-culture area coincides with the written sources' account of the zone where the Sclaveni lived. Located in the Dnieper area, the Penkovka and the Kolochin cultures certainly have a common origin; nevertheless, as it has already been stated, the Penkovka-culture area coincided with the zone where the Antes lived according to the ancient writers, and the Antes were the closest relatives of the Sclaveni. Regarding the northern cultures in the forest zone, every ethnic attribution would remain nothing but speculation due to the lack of support from archaeological sources.

It is important to note that this is the case of cultural identification of archaeological sites, which does not address the questions of language, identity, and political allegiance of the peoples of the said cultures. One should bear in mind that all the ancient ethnonyms mentioned by written sources often indicated the political orientation of a certain group of ancient population and sometimes pointed to very different archaeological realities. An example could be the Ipoteşti-Cîndeşti culture: according to written sources, it undoubtedly occurred in the zone of Slavic settlement, and its people most likely considered themselves Slavs, though it also comprised a very important non-Slavic cultural component. On the contrary, the Antes or the people of the Penkovka culture, who were the closest relatives of the Slavs in cultural respect, and, according to the ancient writers 
(Procopius and Jordanes), had the same ethnonym as the Sclaveni, clearly opposed themselves to the latter. Therefore, the cultural identity of ancient population could partially coincide with its ethnic identity, and thus reliable ethnic identifications are only possible in the case in which sources other than solely archaeological ones are available, primarily the evidence left by ancient writers. Hereinafter, the term "Slavs" is applied in its archaeological sense, referring to the cultural characteristics of an ancient population, primarily the people of the Prague, the Penkovka, and the Kolochin cultures.

There are two specific aspects of the archaeology of Slavic migrations: the movement of the populations of the Slavic cultural model and the diffusion of this model amid non-Slavic populations. Certainly, both phenomena occurred; however, a pure diffusion of the Slavic model would hardly be possible, in any case in which a long period of time when the populations of different cultural traditions lived close to one another is assumed. Moreover, archaeologists researching Slavic antiquities do not accept the ideas produced by the "diffusionists," because most of the champions of the diffusion model know the specific archaeological materials poorly, so their works leave room for a number of arbitrary interpretations (for details, see Pleterski 2015: 232).

Researchers use the following to determine cultural features as archaeological indicators testifying to the Slavic presence in a given area:

- hand-formed vessels of specific forms, usually produced by women for domestic needs, within the context of family traditions;

- cremation burials with very restricted grave goods, often placed into urns of typical Slavic shapes;

- "ordinary" female attire, which in archaic societies used to bear sacral meaning and therefore preserved ethnographic features of the costume of one or another ancient population; nevertheless, specific elements of this attire could have different origins;

- dwellings of small size, with their lower part sunken into the ground and a stove in the corner. Despite climatic conditions, these houses appeared to a varying extent almost everywhere in the zone populated by the Slavs.

From the $5^{\text {th }}$ to the $7^{\text {th }}$ century CE, the peoples of Slavic cultures settled simultaneously in different locations.

\section{Slavic movement into the forest-steppe zone of Eastern Europe}

There were great migrations of Slavic populations in the forest-steppe area, in the Penkovka-culture area. Before the mid-5th century CE, this forest-steppe zone was populated by the people who created the sites of the Chernyakhov (Chernyakhiv, Chernihiv, Černjaxiv) culture culture, corresponding to the Gothic tribal union, a great part of which were pressed to the west by the Huns. The earliest sites of the Penkovka culture appeared in this area in the $5^{\text {th }}$ century CE, in the territory from the left bank of the Dnieper (Poltavcy and Xicci) to the Pivdennyi Buh (Southern Bug; Kunja, Ščurivci, and Kisljak; Gorjunov 1981: 79, 80; Prixodnjuk 1998: 45, 46; map 3). Moreover, researchers have noticed that the Penkovka-culture sites in the Pivdennyi Buh area contained a great deal of typical features of the Prague culture, whose territory was to the northwest of the Penkovka area (map 3). Quite possibly, there was a population of mixed origin, of the Penkovka and 
the Prague cultures (Rusanova 1976: 110). In the 6th century CE, the Penkovka-culture population moved to the east as far as the Donets. Drastic changes in the forest-steppe area near the Dnieper occurred in the $7_{\text {th }}$ century CE, when the region sustained the thrust from the nomads of the steppe, most likely the Bulgars. In the 620s-640s CE, a group of non-coin treasures was hidden (the so-called antiquities of the Antes, or the hoards of the Martynivka [Martynovka] type, in particular the jewels and elements of costumes and in certain cases discovered directly on the sites of the Penkovka and Kolochin cultures), and the number of the Penkovka-culture settlements decreased. There appeared settlements and nomadic stations featuring pottery of obviously southern origin, including such large sites as Pastyrs'ke, rich graves and/or memorial sites of steppe elite such as the famous find in Mala Pereshchepyna. Simultaneously, according to the archaeological sites in possession, some groups of the Slavic population of the Prague culture moved to the middle Dnieper area. There they created the sites of the type Sakhnivka, notable for ceramic ware of globular forms, sometimes with primitive line-and-waveform designs. Another impact from the steppe was probably related to the expansion of the Khazars, experienced in the middle Dnieper area in the last third of the 7 th century CE. The next series of hoards was buried, the Penkovka culture sites finally disappeared, and the Pastyrs'ke site was devastated. In right-bank Ukraine, the Sakhnivka-type antiquities gradually turned into the East Slavic Luka-Raykovetskaya ([Luka-]Rajkivec'ka[ja], [Luka-]Rajkovec'ka[ja]) culture (8th and 9th cc. CE); the latter belonged to the Polans (Poljane, Polianians), the Drevlians (Drevljane, Drevlyans), the Ulichs (Uliči), the Volhynians (Volynjani), and the Dregoviches (Dregoviči) of the Rusian chronicles (Rusanova 1973). In the Dnieper area, there appeared also the sites of the Volyntsevo (Volyncivs'ka) type, with their culture continuing the Prague culture to become the initial stage of the Early Slavic Romny (Romny-Borshevo [Romeno-Borščevs'ka]) culture in the left-bank Dnieper area, relatable with the Severians (Severjane) and the Radimichs (Radimiči) of Rusian written sources (they are also dated to the 8th and gth cc. CE; Grigor'ev 200o). Since the sites of the Sakhnivka and the Volyntsevo types originate from the Prague culture tradition, there are reasons to suppose Slavic expansion from the Prague culture area into the forest-steppe area on the Dnieper in the second half of the 7 th and early 8th centuries CE, possibly with support from the nomads of the steppe, the Bulgars and the Khazars. To the east and south of the Slavs, in the steppe area on the Dnieper, from the 8th century CE on, the people of the Saltov culture settled; these are related to the Alanic and Bulgar population of the Khazar Khanate (Kazanski 2013; Kazanskij and Cukerman 2017). 


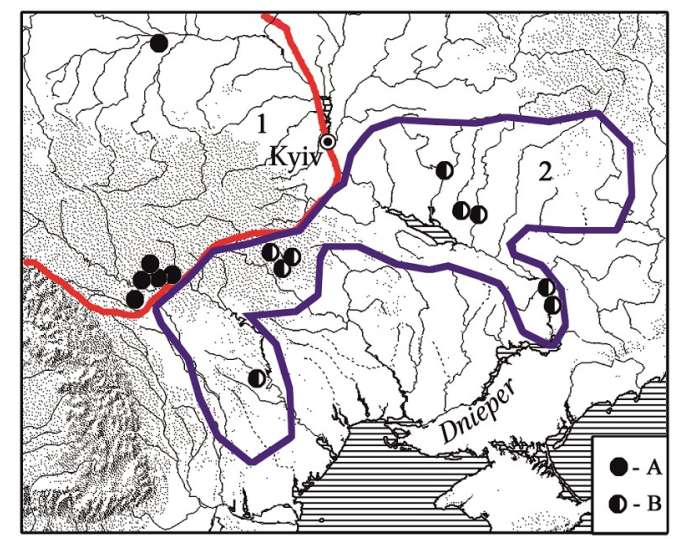

Map 3: Distribution of the earliest sites of the Prague and Penkovka (Pen'kivka) civilizations ( 5 th c. CE; on the basis of Ščukin et al. 2006: fig. 142B). 1 -southern border of the Prague civilization; 2 - area of the Penkovka civilization. A - early sites of the Prague civilization; B - the early sites of the Penkovka civilization. Due to the scale of the map, the areas of distribution of archaeological civilizations and the localization of monuments are shown approximately.

Migration processes from the $5^{\text {th }}$ to the $7_{\text {th }}$ centuries CE with the participation of Slavic population have been documented in the upper Don area. In the $5^{\text {th century CE, there }}$ appeared the Čertovickoe-Zamjatino cultural group, obviously of foreign origin. Apart from other groups, it shaped with the participation of the Kiev-culture population, which most researchers identify with Proto-Slavs (Oblomskij 1999). A new wave of migrants from the west (the Dnieper basin) has been documented there by the appearance of the Kolochin culture in the late 6th and 7 th centuries CE. Apart from "classical" features of the Kolochin culture, the materials from the sites in question possess ornaments typical of the Finnish antiquities in the forest zone of Eastern Europe (Oblomskij 2016: 16, 17). As for the hypothetical migration of the Slavs farther to the east, to the middle Volga basin, where they are ascribed to the Imen'kovo culture (Sedov 1995: 193-197), this interpretation seems improbable due to the lack of support from archaeological materials.

\section{The Slavs' settlement in the lower Danube area and in the Balkan Peninsula}

The region in between the upper Prut and Pripyat, where the earliest sites of the Prague culture appeared, such as Ostrov in the Polesia (Poles'e) area and Kodyn in the Prut area, became the starting point of the migration of the Sclaveni, the peoples of the culture mentioned (Rusanova 1976: 12-55; map 2). This territory coincides with the zone of Palaeoslavic hydronyms in right-bank Ukraine (Trubačev 1968: 270, map 11).

Gradual penetration of the Prague culture people to the south, to the territory of present-day Moldova and Romania, has been related particularly to the distribution of specific ceramic vessels and dwellings with stoves (Rusanova 1976: 98-100, illustration 28; see map 4). The Penkovka-culture people also moved there from the east, from the other side of the Dniester, so the archaeological sites to the west of the Dniester possessed the features of both the Prague and the Penkovka cultures (Rusanova 1976: 100). According to 
the finds of specific metal artefacts, the earliest Slavic sites, Selişte in Moldova in particular, date from the $5^{\text {th }}$ century CE (Gavrituxin and Kazanskij 2018).

According to written sources, the Sclaveni and the Antes entered the lower Danube area no late than $527 \mathrm{CE}$, most likely coming from the east and the northeast, from the basins of the Prut and the Dniester; possibly there were a few repeated waves of migrants. On the left bank of the lower Danube, in present-day Romania, the Slavic presence has been documented in settlements such as Suceava-Şipot and cemeteries such as Sărata-Monteoru. There, the main bulk of the discovered materials, such as radiate-headed brooches with five knobs on the headplate, derived from Gaepidic brooches (Crucea lui Ferentz, Vinderei; see Kazanskij 2014: 186-191), or crossbow brooches of the Byzantine tradition, dates to the 6th century CE. According to Romanian archaeologists, these antiquities suggest that in the Ipoteşti-Cîndeşti or Ciurel culture, a non-Slavic Romanized population predominated. There was, in fact, wheel-made non-Slavic pottery, typical of autochthonous population dwellings with an open fireplace or outside stove, and metalware of the Byzantine tradition, which were also widespread in the Slavic sites in other regions. With respect to the culture, Slavic features are vividly expressed in the lower Danube area: there are pit houses with stoves, handmade vessels, which often predominated $(60 \%$ in the settlement of Suceava-Şipot), typical cremation burials, and sets of artifacts typical of Slavic sites in other countries. The peoples of both Roman and Slavic cultural traditions dwelt in the same villages; the neighbors possibly understood them as being the Sclaveni and the Antes, since only these peoples were known to Byzantine writers as a settled population in the areas in question. Although Romanian researchers have considered the possibility that the Slavs permanently settled the lower Danube area as late as the second half of the 6th century CE, this interpretation contradicts the accounts of Procopius and (Pseudo)-Maurice, who repeatedly identified the Sclaveni and the Antes as the permanent residents of the lands on the left bank of the Danube as early as the first half of the 6th century CE. Moreover, the chronology of the 6th-century CE archaeological materials documented at the sites in modern Romania is not beyond question, as suggested by Romanian scholars.

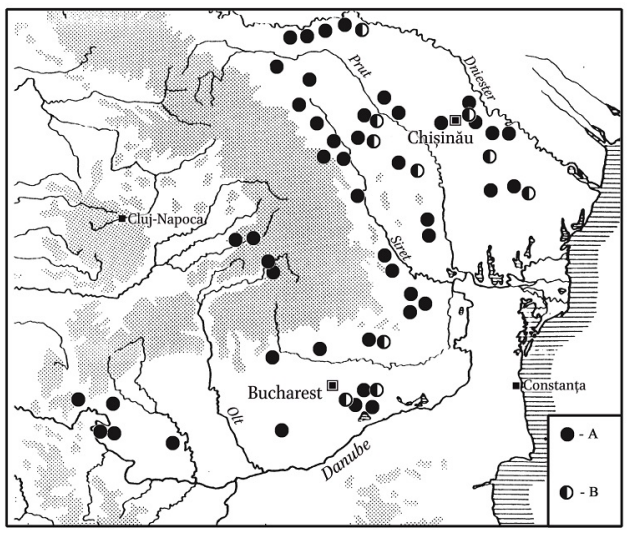

Map 4: Sites with Slavic ceramics of the 6th-7th centuries CE on the left bank of the lower Danube. A - ceramics of the Prague type; B - ceramics of the Penkovka (Pen'kivka) type (on the basis of Teodor 1994: fig. 1). Due to the scale of the map, the localization of the monuments is shown approximately. 
In the territory of present-day Romania, there are materials of both the Prague and the Penkovka cultures, primarily their specific hand-formed vessels (map 4). The Penkovka pottery appeared basically in Romania's province of Moldova, in between the Prut and the Siret, however it also occurs in Muntanea and the Byzantine forts in Dobrogea (Dobrudja). The Prague-culture vessels occur in a wider area, from the Prut to Oltenia, or the Iron Gates (Comşa 1972; Teodor 1972; 1978: 34-39; 1984; 1994; Sedov 1995: illustration 32; see also map 4). Teodor (1984: 74-76) has mentioned the presence of the "forest" ceramic ware of the Kolochin type in the area of present-day Moldova. In the countries to the north of the lower Danube, there appeared two groups of radiate-headed brooches with five knobs on the headplate, related to the Slavs (Teodor 1992). The so-called Dnieper type of radiate-headed brooches with five knobs on the headplate, which is well-known from the treasures of the Martynivka type from the last third of the 6th and the first half of the 7 th century CE, were made primarily in the centers located in the middle Dnieper area. They are typical of the Penkovka culture and the southern area of the Kolochin culture; the brooches of that type rarely came out of the region in question. Fine radiate-headed brooches with five knobs on the headplate dating from the late 6th and 7 th centuries CE are widely distributed in Central and Eastern Europe among different tribes of settled barbarians (nomadic people never wore radiate-headed brooches). There is a great number of these finds in the Slavic sites, featuring the traces of their production (for example, in Velyki Budky in left-bank Ukraine). Generally, fine radiate-headed brooches with five knobs on the headplate form a good reference point for discovering barbarian cultural tradition in comparison with the Roman-Byzantine one, since the costume of the Romaioi (Byzantine Greeks) lacked radiate-headed brooches.

From the lower Danube basin, the Slavs penetrated into the core of the Carpathian basin, and then to Transylvania, initially occupied by the Gepids in $454-568 \mathrm{CE}$, and later controlled by the Avar Khanate. There appeared the Lazuri-Pişcolt horizon of Slavic monuments from the mid-6th to the first third of the 7 th centuries CE. It comprises unfortified settlements in the lowland, with pit houses with stoves, pottery originated from the Prague culture, and cremation graves. It is not quite clear yet if this migration took place before or after $568 \mathrm{CE}$. There is no clear spatial distinction between Transylvanian sites of Slavic and non-Slavic populations. There is obvious influence of the material culture of the Gepids; there are several sites, such as the settlement and cemetery near the village of Bratei, testifying to the acculturation of Slavs and other population groups. After the mid-7th century CE, new groups of Slavic populations penetrated into Transylvania. In the 8th century CE, there appeared a new wave of Slavic migrants, who introduced barrows with cremations in urns and wooden boxes. Most likely, Slavic colonization of the country developed under the control of the Avar Khanate. Generally, the sites from the 7 th to the 9th centuries CE in this country are the result of the melding of different cultural groups, the Slavs in particular (Stanciu 2011; 2015).

In the Balkan Peninsula to the south of the Danube, in the period of Slavic migration, there continued to live numerous non-Slavic populations, particularly in the western half of the peninsula, where the Koman (Komani) archaeological culture of autochthonous origin appeared (see, for example, Nallbani 2002), and in Greece (see, for example, Avramea 1997; Lambropoulou 2009). Generally, the collapse of the socioeconomic system of the Late 
Antiquity as a result of invasions caused a simplification of the material culture of the autochthonous population.

The geographical location of coin hoards (more than three hundred hoards are known so far) indicates the area that suffered such invasions. From $539-540 \mathrm{CE}$ to $578-582 \mathrm{CE}$, barbarians attacked the central area in the Balkans from the Iron Gates to Thessaloniki. From 584-586 CE to 601-602 CE, the eastern area on the Balkans was devastated, and southern and central Greece appeared in the zone of invasions in $570-571,574,578-582$, 584-586, 610-620, and 623-628 CE. This geographical distribution could not be explained by pure economic problems, such as the inflation of bronze coins, especially because the hoards contained, among others, gold coins, which never devalued (Ivanišević 2006: maps $2-8)$.

Written sources allow us to highlight the evolution of Slavic raids. The Antes took an active part in these campaigns as late as the 540s CE, and later became the allies of the Byzantine Empire, so the new wave of raids was made by the Sclaveni. In the initial stage, these raids were made in order to plunder. However, in $5^{81}$ CE the Sclaveni established permanent settlements in Greece, thus starting the age of Slavic colonization of the Balkans, which ended in the 650s CE. From the 580 os CE on, there appeared many instances in which the Slavs were inspired or commanded by the Avars. The Slavs, and primarily their leaders, were gradually acculturated.

On the right side of the lower Danube, archaeological traces of Slavic presence in the 6th and 7 th centuries CE first appeared in Byzantine forts and in their environs (see map 5). There are pottery of the Penkovka culture and, rarely, the Prague culture, as well as fine radiate-headed brooches with five knobs on the headplate (for example, in Dinogetia, Iatrus, and Kaleto). There are inhumation graves with radiate-headed brooches with five knobs in the cemeteries of some frontier forts. Although the inhumation rite is not typical of the Slavs, but rather of the Romaioi, radiate-headed brooches with five knobs were a part of barbarian female attire, which was also popular among the Slavs. Therefore, the graves under present study and their parallels from the areas to the south of the Danube testify to the incorporation of barbarians, possibly the Slavs, into the Byzantine environment and their gradual acculturation. In the territory of western Bulgaria, to the south of the Danube border, quite recent excavations have discovered the settlements of the Valchedram-Yakimovo type, featuring handmade pottery of Slavic types, including rather late vessels with linear and wavelike designs from no earlier than the 7 th century CE. On the territory of present-day Bulgaria, there also are later sites, dating from the $7^{\text {th }}-9$ th centuries CE (Džedžovi lozja, Starica, Garvan, Popina, and others; see map 5). These settlements feature Slavic ceramic ware, pit houses with stoves, and flat cemeteries with urn cremations (Văžarova 1965; Xrisimov 2015).

To the west, on the territory of present-day Serbia, on either side of the Danube, there are several Slavic settlements from the $7^{\text {th }}$-9th centuries CE, featuring pit houses with stoves and globular vessels, sometimes with linear and wavelike designs (Arpatin, Magareći, Mlin, Dubovac, Košića, Breg). No grave has been found so far to be related to the Slavs with a degree of certainty. Nevertheless, the earliest finds of Slavic pottery derived from the vessels of the Prague-culture and fine radiate-headed brooches with five knobs on the headplate appeared in layers of Byzantine forts from the 6th and early 7 th centuries CE, especially 
located close to the Iron Gates (Veliki Gradac, Done Butorki, Hajdučka Vodenica), which might be evidence of Slavs being attracted to the defense of Byzantine borders (Radičevič 2015).

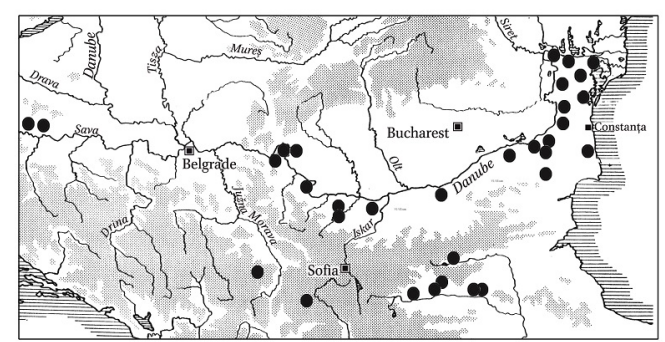

Map 5: The earliest Slavic finds south of the Danube (on the basis of Rusanova 1976: fig. 71; Teodor 1994: fig. 1; Radičević 2015: fig. 1; Xrisimov 2015: fig. 1). Due to the scale of the map, the localization of sites is shown approximately.

The Prague-culture pottery is well known in Illyricum and to the south of the Danube (map 5), for example in Stenevec and Oslek. From the 7 th-8th centuries CE, there are finds of globular vessels of the Slavic type, often with linear and wavelike patterns, at the places of earlier Greco-Roman settlements. There are also known cremated burials containing similar pottery. In the areas mentioned, there are multiple finds of fine radiate-headed brooches with five knobs on the headplate, testifying to the presence of the barbarians, and in Caričin Grad (Justiniana Prima), there appeared a brooch of the Dnieper type, an artifact of purely Slavic origin. More complicated is the case of handmade ceramic vessels of globular shape. Some of them could originate from the Slavic tradition, and a great number of vessels of the kind could appear to replace the Early Byzantine wheel-made pottery, which disappeared after the economic collapse (Rusanova 1976: 189; Sedov 1995: 29, 162; Jankovič 2015; Zečević 2019). The date when the Slavs started settling in Illyricum remains a question. In Vinski's opinion, the Slavs strengthened their position in the area when they were under the aegis of the Avar Khanate (Vinski 1971). This generally coincides with the chronology of the Slavic sites in the zone under study. However, this question remains open because Slavic archaeological materials in the region under discussion have been insufficiently studied. 


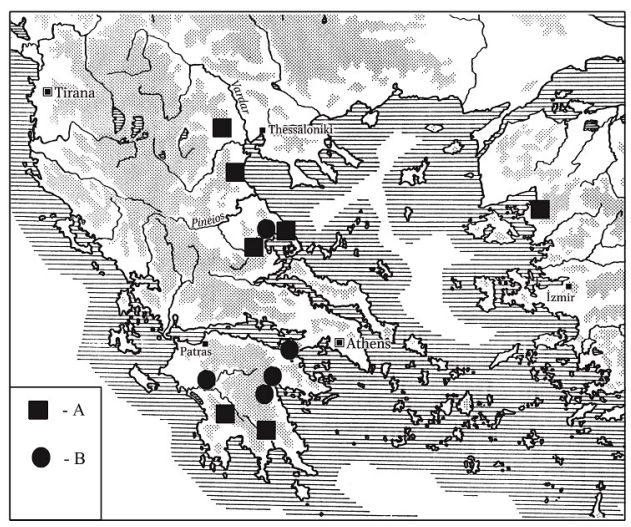

Map 6: Finds of Slavic ceramics of the 7th-8th centuries CE and barbarian radiate-headed "small" brooches in Greece. A brooches; B - ceramics. 1 - Demetras, Hea Anhialos; 2 - Olimpia; 3 - Korinth; 4 - Tiryns; 5 - Argos; 6 - Kiphia Petra, Edessa; 7 Dion; 8 - Messene; 9 - Sparta; 10 - Pergamon (on the basis of Karsougiannopulou 20og: fig. 9 ; Vida and Völling 200o: fig. 9). Due to the scale of the map, the localization of the monuments is shown approximately.

According to the extant written sources, the Slavs settled in Greece from the 580 os CE on. Although there are coin hoards documenting military incursions in $570 / 571,574,578-582$, 584-586, 610-620, and 623-628 CE, there are no Slavic archaeological materials dating to the period earlier than the developed 7 th century CE in this region (see map 6). The most striking site is the cemetery in Olympia, where cremations into Slavic-type urns from the mid-7th to the 8th century CE were found (Vida and Völling 2000). Slavic globular vessels with linear and wavelike designs from the same period were excavated in Argos, Demetrias, Isthmia, and Tiryns. Globular hand-formed vessels from the inhumation grave in Korinthos and hand-formed vessels from Messene are less typical of the Slavic tradition (Vida and Völling 2000: 3-26, 32-40). Fine radiate-headed brooches with five knobs on the headplate typical of the barbarians were found at a number of sites, particularly the 7 th-century CE inhumation grave in Edessa, the latter possibly testifying to the acculturation of the Slavs (Vida and Völling 2000: 27-32; Katsougiannopoulou 2009). It is important to mention the finds of anthropomorphic and zoomorphic figurines in Velestino. They certainly belonged to the barbarian tradition and resembled some of the goods from the hoards discovered in the Dnieper area, of the Martynivka-treasure tradition; however, their Slavic attribution demands further and more advanced arguments.

\section{The Slavs in the middle and upper Danube areas}

In the northern Danube area, where present-day Slovakia, Moravia, Czech Republic, and Upper Austria are located, the Prague-culture people appeared in the 6th century CE (map 7). The Prague culture was brought into the northern Danube area already formed, from the territories of present-day Ukraine and Poland. According to available written sources, Slavic military presence in the area in question relates to the struggle of Prince Ildigis of the Lombards for the crown in 539-549 CE, when he initially escaped to the Slavs, and later invaded the Lombards on the Danube commanding a Slav army (Kazanskij 2014: 180-181). 
There are known unfortified settlements and flat cemeteries typical of the Prague culture. They occupied lowlands at places of strategic importance along the roads and at river fords, leaving mountainous areas nonsettled. Some researchers think that the Slavic settlement went from the Danube up the rivers, despite the discovery of early sites of the Prague culture in the upper reaches of these rivers. To judge by the dense concentration of the sites, another flow of Slavic migrants came from the north through the Moravian gates (see map 7). The chronology of Slavic antiquities relies mainly on the typology of ceramic vessels. According to Carbon-14 analysis, the earliest sites date from the 6th century CE: Běchovice near Prague is from the year $525( \pm 100) \mathrm{CE}$, and Suchohrad in present-day Slovakia from 420-570 CE. Although the Prague-culture people mostly occupied these areas when the Germanic population had already disappeared, there are a few cases of possible Germanic-Slavic contacts and even settlements with cohabitation, for example, according to the finds from the settlement of Březno (Pleinerová 2007), or isolated ceramic finds of the Prague culture in the Lombard funeral context. The bulk of the Prague-culture sites in the northern Danube area dates from the late 6th and 7 th centuries CE, based on the finds of Byzantine, Avar, and, rarely, Merovingian artifacts. From that moment on, the territory in question became the zone of total and stable Slavic settlement (Zeman 1976; Klanica 1986; Fusek 1994; Szameit 1996; Elinkova 2015; Profantova 2015; Fusek 2015).

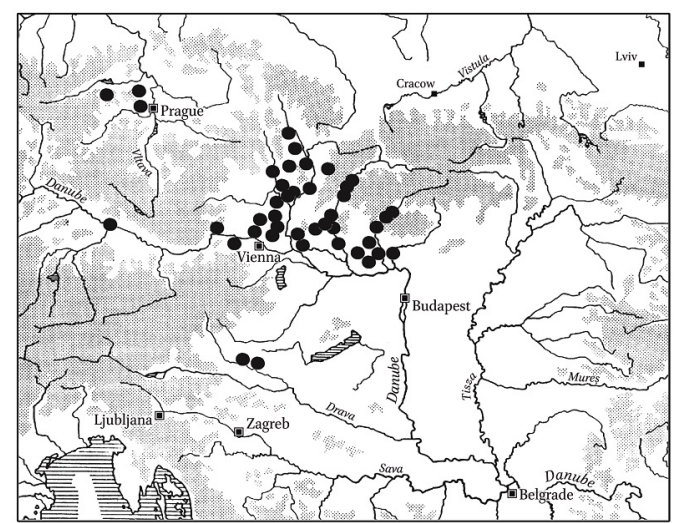

Map 7: The earliest Slavic sites on the middle Danube (6th c. CE; on the basis of Rusanova 1976: 126-129; Profantová 2015: 101-102; Jelínková 2015: 119; Fusek 2017: fig. 7; Szameit 1996: fig. 2). Due to the scale of the map, the localization of the monuments is shown approximately.

In the 7 th century CE, Slavic sites appeared in the area south of the Danube, in the territory of present-day Austria (Szameit 1996: fig. 3). In Pleterski's view, independent groups of the Slavic people of the Prague culture penetrated into the eastern Alps, or the area between the Danube and the Adriatic Sea, from the first third of the 6th century CE onward (map 7 ). There are several settlements containing vessels similar to Prague ware. Its Carbon-14 dates are 543 and 547 CE (Nova Tabla settlement) and 535 CE (Pod Kotom settlement; Pleterski 2015).

For any research on Slavic migrations to the upper Danube area, especially important is the cemetery of Regensburg-Großprüfening in Bavaria, comprising 22 Slavic cremation graves, where Merovingian goods also appear. It has been presumed that the migration of the Slavs, 
most likely of a certain group of elite warriors, to this area occurred in about $568 \mathrm{CE}$, when they were pressed by the Avar expansion and obviously received permission from the Duke of Bavaria (Losert 2011).

\section{The migration of the Slavs toward the Vistula, the Oder, and the Elbe basins}

Currently, Kazimierz Godłowski's interpretation is generally accepted that, in the 6th and 7 th centuries CE, the Slavic people of the Prague culture migrated to the west from the east, from what is now Ukraine and Belarus, and occupied the land abandoned by the Germanic populations in the course of the Great Migration, in the late 4 th and the $5^{\text {th }}$ centuries CE (Godłowski 1979; 1983).

On the territory of present-day southern and middle Poland, there are very few archaeological sites from the $5^{\text {th }}$ century CE. There is a great number of later sites of the Prague culture, mostly in the upper and middle Vistula basin, the Warta, and the upper and middle Oder area. Moreover, the earliest of the sites featuring the most archaic pottery dating to the 6th century have been discovered in the upper Vistula and the middle Oder areas (Parczewski 1993: fig. 24; see map 8). The Prague-culture people moved there from the east or the southeast, plausibly along the northern branches of the Carpathians. Polish Pomerania and the countries to the north of the middle Vistula remained unpopulated in the first half of the 6th century CE (Parczewski 1993).

The Slavs settled in the basins of the Elbe and the Oder, in the areas that had been formerly populated by Germanic tribes. The latter left these places by the turn of the 6th century CE. The contacts with Germanic populations living to the west of the Saale-Elbe line are documented primarily by ceramic ware of Germanic appearance discovered at the settlement of Dessau-Mosigkau and the presence of isolated artifacts of the Germanic tradition. In the Havel-Spree region, and on the island of Rügen, pollen analysis undertaken at the settlements where Germanic and Slavic pottery appeared has uncovered the continuity of plowland and therefore the continuity of settlement. However, the aggregate of pollen-analysis data for the region between the Oder and the Elbe has shown that the Germans left this zone in general, so it was covered with growing forest before the Slavs arrived. According to the concentration of Slavic settlements and their size, the Slavs settled there as small groups, which was probably related with their slash-and-burn agriculture (Sedov 1995: 47). 


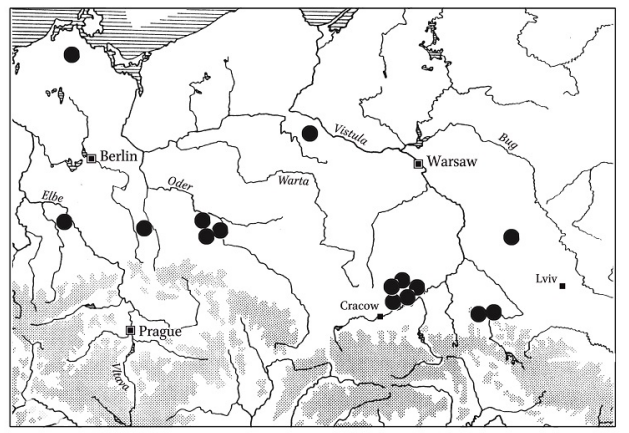

Map 8: The territory of the Prague civilization and the Sukow-Dziedzice group north of the Carpathians and the earliest sites (6th c. CE; on the basis of Rusanova 1976: figs. 49, 63; Parczewski 1993: fig. 24). Due to the scale of the map, the areas of distribution of archaeological civilizations and the localization of sites are shown approximately.

In the basins of the Oder, the Elbe, and the Saale, the earliest Slavic settlement and cemetery sites belong to the Prague culture (Brachmann 1978; Herrmann 1985: 21-32; Brather 2008: table 8; see map 8). They concentrated in the upper Elbe area and near the Saale, rarely in the Oder-Spree basin (Rusanova 1976: 149-151). Perhaps this geographical distribution indicates the movement of the Slavs through the Elbe basin, starting from the northwest of the modern Czech Republic. Perhaps this migration was caused by the Avar pressure or initiated by the Avars (Krüger 1967: 674; Rusanova 1976:142). Local sites actually possessed the pottery of the types later than those in the Czech Republic. The oldest Slavic sites in the Elbe-Saale basin date from the late 6th century CE; according to Carbon-14 chronology for the settlement of Dessau-Mosigkau, dwelling 6 dates to the year 590 CE $( \pm$ 8o). The earliest of datable artifacts from the Slavic sites in the Elbe-Saale basin also date from the Avar period (Rusanova 1976: 144-145). Globular vessels of the Rüssen type featuring the line and wavelike designs (Brachmann 1978: 95-105) plausibly appeared in the Elbe-Saale region in the 7 th century CE to replace the Prague ware; according to some researchers, the appearance of this type of ceramic was related to the migration of a new population group of the Slavs coming from the middle Danube (Sedov 1995: 142, 143). This group of sites has been allegedly identified with the Serbians known in this area from the 630s CE (Brachmann 1979). From the 7 th century CE on, according to available archaeological sources, the Slavs began to penetrate into Thuringia, to the west of the Saale; by the 9 th century CE, there appeared many sites featuring Slavic materials (Dušek 1983).

In the western area of Polish Pomerania, in the northern area between the Oder and the Elbe, to the west of the lower Elbe, that is, in the territory where in the 8th and 9th centuries CE written sources documented Slavic tribes of the Pomeranians, the Veleti-Lutici, and the Obotrites (Obodrites, Obodritae, Abodritae), the earliest Slavic sites known so far are those featuring the pottery of the Sukow-Dziedzice type (Schuldt 1964; Łosiński 1982; Herrmann 1985: 27, 28, fig. 44; Dulinicz 2006; Brather 2008: 199, table 9). The Sukow ware is derivative of the Prague-culture vessels (Rusanova 1976:152, 153). The earliest dendrochronological date for the settlement of Sukow corresponds to circa $591 \mathrm{CE}$, and the finds from the settlement of Bosau-Bischofswarder possess a Carbon-14 dating of 599 CE $( \pm 53$; Dulinicz 2006: 44, 52, tables 2, 6). From the late 7 th and the 8th centuries CE, the evolution of the Sukow group resulted in the appearance of the Slavic groups of Feldberg in Pomerania and 
Mecklenburg, and Tornow in the upper Oder area (Herrmann 1973; Brather 2008: 199, table 9). Their pottery and dwellings, as well as portable artifacts, reflected western, or Germanic, influence (Sedov 1995: 51-56, 138-147). Simultaneously, sites with globular vessels featuring the linear and wavelike designs, typical of the entire world of the Slavs in the 8th and 9 th centuries CE, predominated in southern and middle Poland.

\section{Slavic migration in the forest area of Eastern Europe}

In the forest zone of Eastern Europe, the Slavic migrations continued as long as the 9 th century CE. In the upper Dnieper area during the Great Migration period, there are striking traces of military action from the mid-5th to the first half of the 6th century CE. Among them are fortified settlements that perished in conflagration, supplying a big number of weapons, such as Demydivka. Simultaneously, there appeared weapons of "western" types and artifacts of the prestigious "warrior" culture of the Central European type. These testify to some military events, most likely related to the appearance of groups of foreign warriors in this region (Kazanski 2000a; Axmedov and Kazanskij 2004). Nevertheless, according to the archaeological materials, there was no population change in the upper Dnieper area, since the core of the sites in the region remained the monuments now attributed to the Kolochin culture of the Slavs and dated to the period that lasted until the second half of the 7th century CE (Nikodimovo; Oblomskij 2016: 16).

To the north, in the basins of the Daugava River (Western Dvina), the Lovat, the Velikaya, the Msta, and the Mologa, there appeared the Long Barrows culture (also known as the

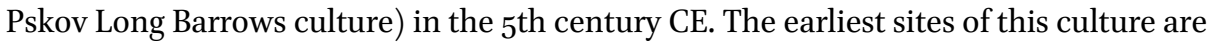
located in the Daugava River area in present-day Belarus, at the upper Msta, at the Mologa, and to the east of Lake Peipus. Handmade ware of this culture originated from the Zaozer'e group from the Roman period, related with the Kiev culture (see above). On the basis of this circumstance, there are reasons to suppose some Proto-Slavic (or Balto-Slavic?) component in the shaping of the Long Barrows culture. However, the complex of hydronyms in the northwest of Russia comprises Early Slavic models of water names coinciding with the Long Barrows-culture area (Sedov 1994: 301). Simultaneously, the antiquities of the northeastern area of this culture show some Finnish influence. There is no doubt that the foreign Baltic element played an important part in the shaping of the Long Barrows culture, since the origins of the rite of funerals in long barrows are in the Baltic-culture area, from the Mazurian lakes to the Daugava River. The ware complex of this culture includes artifacts of Central European and Baltic origin, reflecting its heterogeneous genesis. Quite possibly, the origin of the Long Barrows culture is a manifestation of the military action that took place in the forest zone of Eastern Europe in the Great Migration period (see above; Mixajlova 2014: 205-208, 221-225; Islanova 2016: 136-150).

In the Long Barrows-culture area, there appeared several groups of foreign origin. The Udomel' group comprised flat cemeteries of cremation graves and unfortified settlements. The excavations of the settlement of Jur' evskaja Gorka uncovered pit houses with corner stoves and hand-formed vessels with parallels in the Prague culture. The Ilmen group includes fortified settlements, such as Gorodok on the Majata and Sel'co, and features the pottery originating from the Kiev and the Kolochin cultures. It has been supposed that these groups possibly belonged to the Slavs (Islanova 2016:151-163). 


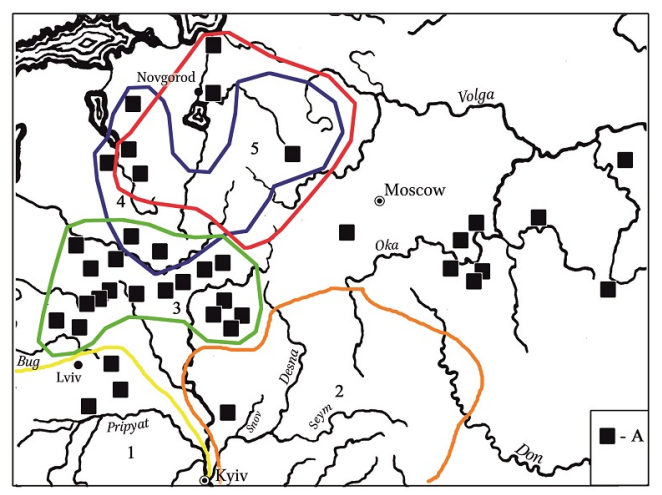

Map 9: Findings of the Danube and Central European origin of the 7 th-8th centuries CE in the forest zone and the region of the archaeological civilizations of the 8th-9th centuries CE, correlated with the Slavs. A - findings of the Danube and Central European origin of the 7 th-8th centuries CE (on the basis of Kazanski 20oob, with additions); 1 - northern border of the Luka-Raykovetskaya ([Luka-]Rajkivec'ka[ja], [Luka-]Rajkovec'ka[ja]) civilization; 2 - the northern border of the Volyntsevo-Romny-Borshevo (Romeno-Borščevs'ka) culture; 3 - civilization of the Smolensk long barrows; 4 -civilization of the Pskov long barrows; 5 - civilization of the Novgorod great barrows. Due to the scale of the map, the areas of distribution of archaeological civilizations and the localization of sites are shown approximately.

In the forest zone, archaeology has documented the distribution of Slavic elements from the second half of the 7 th and 8th centuries CE possibly connected to a new wave of migrants from the south (map 9). The basis for the connection is the appearance of globular vessels with linear and wavelike patterns, artifacts originating from the Danube, such as fine radiate-headed brooches with five knobs on the headplate, temple rings with scroll, bracelets with hollow flaring ends, trapezoidal pendants, late Avar belt sets, early Byzantine buckles, and some types of iron tools in the forest zone (Kazanski 200ob). Plausibly, there were some cases in which this migration wave caused conflicts with the local population, resulting in the destruction of the fortified settlement of Nikodimovo located in the upper Dnieper area in the second half of the 7th century CE (Oblomskij 2016: 6o). Most likely, this migration shaped the Smolensk Long Barrows culture in the upper Dnieper and the upper Dvina area, which comprised Slavic and Baltic features and belonged to the Krivichs known from Rusian and Byzantine written sources (Sedov 1995: 229-238). On the north, the Knoll culture shaped in the gth century CE in the basin of Lake Ilmen. Researchers have related it with the Slavs of Novgorod (Sedov 1995: 238-246) and multiethnic Rus', which included Scandinavian, Slavic, and Finnish elements.

A little farther south, the Slavs penetrated into the upper Oka basin from left-bank Ukraine in the 8th century CE. In the new territory, they created the sites of the type called Volyntsevo (see above). In the 9th century CE, in the upper Oka and the upper Don areas, the Volyntsevo antiquities formed the background for the shaping of the Borshevo culture, which became a variant of the Romny culture (see above). By all appearances, these sites correspond to the people called the Vyatichs (Vyatichi, Viatichi, Viatiči) in the Rusian chronicles (Sedov 1995: 198-203; Grigor' ev 2005; Vinnikov 2014). 
Avramea, Anna 1997. Le Péloponnèse du IVe au VIIIe siècle: Changements et persistances. Paris.

Axmedov, Il'ja R., and Mixail M. Kazanskij 2004. Posle Attily: Kievskij klad i ego kul'turno-istoričeskij kontekst. In: Gorjunova, Valentina M., and Ol'ga A. Ščeglova (eds.), Kul'turnye transformacii i vzaimovlijanija $v$ Dneprovskom regione na isxode rimskogo vremeni i v rannem srednevekov'e. St. Petersburg, 168-202.

Brachmann, Hansjürgen 1978. Slawische Stämme an Elbe und Saale. Zu ihrer Geschichte und Kultur im 6. Bis 10. Jahrhundert - aufGrund archäologischer Quellen. Berlin.

Brachmann, Hansjürgen 1979. Historische und kulturelle Beziehungen der Sorben zu Böhmen und Mähren. In: Chropovský, Bohuslav (ed.), Rapports du IIIe Congrès International d'Archéologie Slave: Bratislava, 7-14 septembre 1975, vol. I. Bratislava, 117-124.

Brather, Sebastian 2008. Archäologie derwestlichen Slawen. Siedlung, Wirtschaft und Gesellschaft im früh- und hochmittelalterlichen Ostmitteleuropa. Berlin.

Comşa, Maria. 1972. Directions et étapes de la pénétration des Slaves vers la péninsule balkanique aux Vie-VIIe siècles (avec un regard spécial sur le territoire de la Roumanie). Balcanoslavica 1, 9-28.

Dulinicz, Marek 2006. Frühe Slawen im Gebiet zwischen unterer Weichsel und Elbe. Eine archäologische Studie. Neumünster.

Dušek, Sigrid 1983. Geschichte und Kultur der Slawen in Thüringen. Weimar.

Fusek, Gabriel 1994. Slovensko vo včesnoslovanskom období. Nitra.

Fusek, Gabriel. 2015. Drevnee slavjanskoe naselenie na territorii Slovakii. Stratum plus 5, 151-162.

Gavrituxin, Igor' O., and Mixail M. Kazanskij 2018. O vremeni pojavlenija slavjan na territorii Moldovy. In: Sinika, Vitalij S., and Roman A. Rabinovič (eds.), Drevnosti:

Issledovanija: Problemy: Sbornik statej v čest' zo-letija N.P. Tel'nova. Chișinău, 333-354.

Godłowski, Kazimierz 1979. Z badań nad zagadnieniem rozprzestrzenienia Stowian w V-VII w. n.e. Cracow.

Godłowski, Kazimierz. 1983. Zur Fragen der Slawensitze vor der Grossen Slawenwanderung im 6. Jahrhundert. Settimane di studio del Centro italiano di studi sull'alto medioevo 30 , 257-302.

Gorjunov, Evgenij A. 1981. Rannie ètapy istorii slavjan Dneprovskogo Levoberežjja. Leningrad. 
Grigor'ev, Aleksandr V. 200o. Severskaja zemlja v VIII - načale XI veka po arxeologičeskim dannym. Tula.

Grigor'ev, Aleksandr V. 2005. Slavjanskoe naselenie vodorazdela Oki i Dona v konce I - načale II tys. n.e. Tula.

Herrmann, Joachim 1973. Die germanischen und slawischen Siedlung und das mittelalterliche Dorfvon Tornow, Kr. Calau. Berlin.

Herrmann, Joachim (ed.) 1985. Die Slawen in Deutschland. Geschichte und Kultur der slawischen Stämme westlich von Oder und Neisse vom 6. bis 12. Jahrhundert. Berlin.

Islanova, Inna V. 2016. Rannesrednevekovye gruppy pamjatnikov na Severo-Zapade Vostočnoj Evropy. In: Oblomskij, Andrej M., and Inna V. Islanova (eds.), Rannesrednevekovye drevnosti Vostočnoj Evropy (V-VII vv.). Moscow, 136-220.

Ivanišević, Vujadin 2006. Les trésors balkaniques, témoins des invasions et de leurs routes. In: Morisson, Cécile et al. (eds.), Les trésors monétaires byzantins des Balkans et d'Asie Mineure (491-713). Paris, 75-93.

Jankovič, Džordže. 2015. O slavjanizacii Severnoj Illirii i Dalmacii. Stratum plus 5, 249-308.

Jelínková, Dagmar. 2015. K izučeniju kul'tury s keramikoj pražskogo tipa na territorii Moravii: Formirovanie i osobennosti. Stratum plus 5, 117-150.

Katsougiannopoulou, Christina 2009. The Slavic bow brooches in Greece revisited: Some remarks on ethnicity and social status. In: Quast, Dieter (ed.), Foreigners in early Medieval Europe: Thirteen international studies on early Medieval mobility. Mainz, 219-231.

Kazanski, Michel 1999. Les Slaves : Les origines (Ier - VIIe siècle après J.-C.). Paris.

Kazanski, Michel 200oa. La zone forestière de la Russie et l'Europe centrale à la fin de l'époque des Grandes Migrations. In: Mączyńska, Magdalena, and Tadeusz Grabarczyk (eds.), Die spätrömische Kaiserzeit und die frühe Völkerwanderungszeit in Mittel- und Osteuropa. Łódź, 406-459.

Kazanski, Michel 20oob. Les Slaves dans la zone forestière d'Europe orientale au début du Moyen Age. In: Kazanski, Michel. 2013. The Middle Dnieper area in the seventh century: An archaeological survey. Travaux et Mémoires 17, 769-864.

Kazanski, Michel et al. (eds.) 200o. Les centres proto-urbains russes entre Scandinavie, Byzance et Orient. Paris, 17-44.

Kazanskij, Mixail M. 2014. Slavjane i dunajskie germancy v VI veke: Svidetel'stva pis'mennyx istočnikov i nekotorye arxeologičeskie dannye. In: Tokareva, Elena P., and Viktor G. Lušin (eds.), Štrixi k portretam minuvšix èpox: Arxeologija, istorija, ètnografija, vol. I. Zimovniki, $175^{-200 .}$ 
Kazanskij, Mixail, and Konstantin Cukerman. 2017. Uliči. Paleoslavica 25/2, 1-37.

Klanica, Zdeněk 1986. Počátky slovanského osídlení našich zemí. Prague.

Krüger, Bruno 1967. Dessau-Mosigkau. Ein frühslawischer Siedlungsplatz im mittleren Elbgebiet. Berlin.

Lambropoulou, Anna 2009. The Presence of Slavs in the Western Peloponnese during the $7_{\text {th }}$ and 8th centuries. In: Quast, Dieter (ed.), Foreigners in early Medieval Europe. Mainz, $197-217$.

Losert, Hans 2011. Das Brandgräberfeld von Regensburg-Großprüfening und die frühen Slawen in Pannonien - in Gedenken an Marek Dulinicz, Warschau († 2010). In: Heinrich-Tamáska, Orsolya (ed.), Keszthely-Fenékpuszta im Kontext spätantiker Kontinuitätsforschung zwischen Noricum und Moesia. Budapest, 475-489.

Łosiński, Władysław 1982. Osadnictwo plemienne Pomorza (VI-X wiek). Wrocław.

Mitrofanov, Aleksej G. 1978. Železnyj vek srednej Belorussii (VII-VIvv. do n.e. - VIII v. n.e..). Minsk.

Mixajlova, Elena P. 2014. Veščevoj kompleks kul'tury dlinnyx kurganov: Tipologija $i$ xronologija. Saarbrücken.

Nallbani, Etleva 2002. Transformations et continuité dans l'Ouest des Balkans: Le cas de la civilisation de Komani (VIe-IXe siècles). In: Cabanes, Pierre, and Jean-Luc Lamboley (eds.), L'Illyrie méridionale et l'Épire dans l'Antiquité: Actes du IVe Colloque International de Grenoble (10-12 octobre 2002). Paris, 481-489.

Oblomskij, Andrej M. 1999. O ritmax razvitija lesostepnogo Podneprov'ja i Podon’ja v pozdnerimskoe i gunnskoe vremja. In: Bessudnov, Aleksandr N. (ed.), Arxeologija Central'nogo Černozem'ja i sopredel'nyx territorij. Lipetsk, 127-133.

Oblomskij, Andrej M. 2016. Koločinskaja kul'tura. In: Oblomskij, Andrej M., and Inna V. Islanova (eds.), Rannesrednevekovye drevnosti Vostočnoj Evropy (V-VII vv.). Moscow, 10-113.

Parczewski, Michał 1993. Die Anfänge der frühslawischen Kultur in Polen. Vienna.

Pleinerová, Ivana 2007. Březno und germanische Siedlungen der jüngeren Völkerwanderungszeit in Böhmen. Prague.

Pleterski, Andrej. 2015. Rannie slavjane v Vostočnyx Al'pax i na sosednix zemljax. Stratum plus 5, 227-248.

Prixodnjuk, Oleg M. 1998. Pen'kovskaja kul'tura: kul'turno-xronologičeskij aspekt issledovanija. Voronezh. 
Profantová, Nadja. 2015. Slavjane na territorii Čexii i ix kontakty v VI-VII vv. Stratum plus 5 , 97-116.

Radičević, Dejan. 2015. K izučeniju ranneslavjanskix pamjatnikov Serbskogo Podunav'ja (voprosy xronologii i ètnokul'turnoj prinadležnosti). Stratum plus 5, 285-308.

Rusanova, Irina P. 1973. Slavjanskie drevnosti VI-IXvv. meždu Dneprom i Zapadnym Bugom. Moscow.

Rusanova, Irina P. 1976. Slavjanskie drevnosti VI-VIIvv. Kul'tura pražskogo tipa. Moscow.

Šadyra, Vadzim 2006. Belaruskae Padzvinne (I tysjačagoddze n.è.). Minsk.

Schuldt, Ewald. 1964. Die Ausgrabungen im Gebiet der “Alten Burg” von Sukow, Kr.

Teterow. Bodendenkmalpflege in Mecklenburg.Jahrbuch 1963, 217-238.

Ščukin, Mark, et al. 2006. Des les Goths aux Huns: Le nord de la mer Noire au Bas-Empire et a l'époque des Grandes Migrations. Oxford.

Sedov, Valentin V. 1994. Slavjane v drevnosti. Moscow.

Sedov, Valentin V. 1995. Slavjane v rannem Srednevekov'e. Moscow.

Stanciu, Ioan 2011. Locuirea teritoriului nord-vestic al României între antichitatea târzie şi perioada de început a epocii

medievale timpurii (mijlocul sec. V-sec. VII timpuriu) (Inhabitation of the northwestern territory of Romania between late antiquity and the beginning of the early medieval period [mid-5th c. - early 7 th c. CE]). Cluj-Napoca.

Stanciu, Ioan. 2015. Rannie slavjane v rumynskoj časti Karpatskogo bassejna. Stratum plus 5, $163-216$.

Szameit, Erik. 1996. Frühmittelalterlische Slawen in Niederösterreich. Ein Beitrag zum Erscheinungsbild slawischer Populationen des 6.-8. Jahrhunderts in

Ostösterreich. Archäologie Österreichs 7, 21-28.

Teodor, Dan G. 1972. La pénétration des Slaves dans les régions du S-E de l'Europe d'après les données archéologiques des régions orientales de la Roumanie. Balcanoslavica 1, 29-42.

Teodor, Dan G. 1978. Teritoriul est-carpatic în veacurile V-XI e.n.: Contribut,ii arheologice și istorice la problema formării poporului român (The eastern Carpathian territory in the

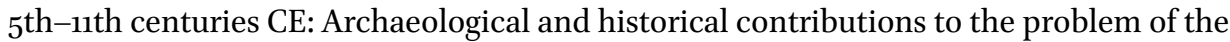
formation of the Romanian people). Iaşi.

Teodor, Dan G. 1984. Origines et voies de pénétration des Slaves au sud du Bas-Danube (VIe-VIIe siècles). In: Villes et peuplement dans l'Illyricum protobyzantin: Actes du colloque (Rome, 12-14 mai 1982). Rome, 63-84. 
Teodor, Dan G. 1992. Fibule “digitate” din secolele VI-VII în spaţiul carpato-dunăreano-pontic (Digested fibulae from the 6th-7th centuries CE in the Carpathian-Danubian-Pontic area). Arheologia Moldovei 15, 119-152.

Teodor, Dan G. 1994. Slavii la nordul Dunări de Jos în secolele VI-VII d.H. (The Slavs north of the lower Danube in the 6th-7th centuries CE). Arheologia Moldovei 17, 223-251.

Tret'jakov, Petr N. 1966. Finno-ugry, balty i slavjane na Dnepre i Volge. Moscow.

Tret'jakov, Petr N. 1970. U istokov drevnerusskoj narodnosti. Leningrad.

Tret'jakov, Petr N. 1982. Po sledam drevnix slavjanskix plemen. Leningrad.

Trubačev, Oleg N. 1968. Nazvanija rek Pravoberežnoj Ukrainy: Slovoobrazovanie: Ėtimologija: Etničeskaja interpretacija. Moscow.

Văžarova, Živka 1965. Slavjanski i slavjanobălgarski selišta v bălgarskite zemi ot kraja na VI-XI vek. Sofia.

Vida, Tivadar, and Thomas Völling 2000. Das slawische Brandgräberfeld von Olympia. Rahden.

Vinnikov, Anatolij Z. 2014. Jugo-vostočnaja okraina slavjanskogo mira v VIII - nač. XIIIvv. Voronezh.

Vinski, Zdenko. 1971. Rani srednji vijek u Jugoslaviji od 40o. do 8oo. godine. Vjesnik Arheološkog muzeja u Zagrebu 5/1, 47-71.

Xrisimov, Nikolaj. 2015. Ranneslavjanskie pamjatniki v severo-vostočnoj časti Balkanskogo poluostrova. Stratum plus 5, 309-342.

Zečević, Emina 2019. Tragovi slovena u 6. i 7. stoleću na Zapadnomu Balkanu. In: Gavrituxin, Igor' O., and Stanko Trifunović (eds.), Balkan, Podunavlje i Istočna Evropa u rimsko doba i ranom srednjem veku. Novi Sad, 407-442.

Zeman, Jiří. 1976. Nejstarší slovanské osídlení Čech. Památky Archeologické 67, 115-235. 